\title{
Chemopreventive effect of dimethyl dicarboxylate biphenyl on malignant transformation of WB-F344 rat liver epithelial cells ${ }^{1}$
}

\author{
Hua SUN, Geng-tao LIU² \\ ${ }^{2}$ Department of Pharmacology, Institute of Materia Medica, Peking Union Medical College \& Chinese Academy of Medical Sciences, Beijing \\ 100050, China
}

\section{Key words}

dimethyl dicarboxylate biphenyl; liver neoplasm; cell transformation; chemoprevention; epithelial cell; gap junctions

\author{
${ }^{1}$ This work was supported by grant \\ 2004AA2Z3814 from the Chinese Ministry \\ of Sciences and Technology. \\ ${ }^{2}$ Correspondence to Prof Geng-tao LIU. \\ Phn 86-10-6316-5178. \\ Fax 86-10-6301-7757. \\ E-mailliugt@imm.ac.cn \\ Received 2005-04-14 \\ Accepted 2005-07-25
}

doi: $10.1111 /$ j.1745-7254.2005.00208.x

\begin{abstract}
Aim: To study the potential chemopreventive effect of dimethyl dicarboxylate biphenyl (DDB), an anti-hepatitis drug, on hepatocarcinogenesis in vitro. Methods: The anti-carcinogenesis effect of DDB was assessed on a two-stage chemical oncogenesis model induced by 3-methylcholanthrene and 12-Otetradecanoyl phorbol 13-acetate (TPA) with WB-F344 rat liver epithelial cells (WB-F344 cells) in vitro. A soft-agar colony formation assay was used to determine the tumorigenic potential of the transformed WB-F344 cells. The gap junctional intercellular communication (GJIC) was detected using the scrape loading/ dye transfer technique. Results: DDB at $1 \mu \mathrm{mol} / \mathrm{L}, 2 \mu \mathrm{mol} / \mathrm{L}$, and $4 \mu \mathrm{mol} / \mathrm{L}$ significantly prevented the malignant transformation of WB-F344 cells induced by $3-$ methylcholanthrene and TPA. The average number of transformed foci decreased dramatically by $10.0 \%, 37.2 \%$, and $47.4 \%$, respectively. In soft agar, a remarkable decrease in colony numbers was observed in transformed cells treated with $2 \mu \mathrm{mol} / \mathrm{L}$ and $4 \mu \mathrm{mol} / \mathrm{L}$ DDB. DDB at $1 \mu \mathrm{mol} / \mathrm{L}, 2 \mu \mathrm{mol} / \mathrm{L}$, and $4 \mu \mathrm{mol} / \mathrm{L}$ inhibited the downregulation of GJIC induced by TPA in a dose-dependent manner. The GJIC recovered to $25.6 \%, 34.6 \%$, and $44.9 \%$, respectively, of the control WB-F344 cells by DDB. Conclusion: DDB has a potential chemopreventive effect on hepatocarcinogenesis induced by carcinogens in vitro.
\end{abstract}

\section{Introduction}

Human hepatocellular carcinoma (HCC) is one of the most frequent malignant cancers. The carcinogenesis of $\mathrm{HCC}$ is a multifactorial event. Chronic hepatitis B virus (HBV) and hepatitis $\mathrm{C}$ virus (HCV) infections are the most frequent causes of $\mathrm{HCC}^{[1]}$. Approximately $80 \%$ of human $\mathrm{HCC}$ are attributable to HBV infection ${ }^{[2]}$. Chronic HBV carriers are $100-400$ times more likely to develop HCC than non-carriers ${ }^{[3]}$. $\mathrm{HCV}$ is the second most common cause of HCC after HBV ${ }^{[4]}$. Currently, HCC represents more than $4 \%$ of all cancer cases worldwide and causes at least 315000 deaths every year ${ }^{[5]}$. Although early HCC can be cured by surgical resection, many $\mathrm{HCC}$ are asymptomatic, so most $\mathrm{HCC}$ patients are not diagnosed in time.

An effective approach to cancer control is chemo- prevention. It is known that the therapy of both chronic $\mathrm{HBV}$ and HCV generally involves a long-term course. An anti-hepatitis drug with an inhibiting or a suppressing effect on the development of hepatocarcinogenesis, besides its improvement of abnormal liver function, would be of great clinical value.

Dimethyl dicarboxylate biphenyl (DDB) is a synthetic analogue of Schizandrin C, which was isolated from Fructus Schizandrae chinensis ${ }^{[6]}$. Since 1983, DDB has been widely used to treat hepatitis B patients in China and is exported to Korea, Egypt, Vietnam, Indonesia, Pakistan, and Burma for the treatment of HBV and HCV. The results of the clinical application indicated that DDB markedly improved impaired liver functions, such as the elevated serum transaminase, bilirubin, $\alpha$-fetal protein, and symptoms of the patients. Pharmacologically, DDB has a protective action against 
experimental liver injury in mice and rats ${ }^{[7,8,9]}$. DDB also had anticancer activity and differentiation-inducing effect on cancer cells ${ }^{[10]}$. In the present paper, the chemoprevention effect of DDB on hepatocellular carcinogenesis in vitro is studied.

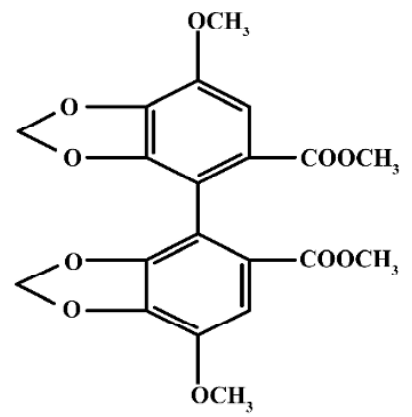

\section{Materials and methods}

Chemicals DDB with $99 \%$ purity was provided by the Beijing Union Pharmaceutical Plant. As DDB is not watersoluble, it was dissolved in dimethyl sulfoxide $\left(\mathrm{Me}_{2} \mathrm{SO}\right)$ for in vitro use. 3-Methylcholanthrene (3MC), 12-Otetradecanoyl phorbol 13-acetate (TPA), MTT, and Lucifer yellow $\mathrm{CH}$ were obtained from Sigma Chemical Company. Other chemicals were of analytical grade and purchased from Beijing Chemical Company.

Cell culture WB-F344 cells were grown in DMEM (GIBCO) media containing 10\% newborn calf serum, $100 \mathrm{kU} / \mathrm{L}$ penicillin, and $100 \mathrm{mg} / \mathrm{L}$ streptomycin in a $37^{\circ} \mathrm{C}$ humidified incubator containing 5\% $\mathrm{CO}_{2}$ and $95 \%$ air, and passaged using $0.25 \%$ trypsin plus $0.02 \%$ EDTA treatment. The culture medium was changed every other day.

MTT assay Cytotoxicity was determined by MTT assay according to the method of Mosmann ${ }^{[11]}$. WB-F344 cells $\left(3 \times 10^{3}\right.$ cells per well) were plated on 96 -well plates, and $24 \mathrm{~h}$ later various concentrations of DDB were added $(0.5 \mu \mathrm{mol} / \mathrm{L}-$ $100 \mu \mathrm{mol} / \mathrm{L}$ ). The cells were incubated at $37^{\circ} \mathrm{C}$ in a $\mathrm{CO}_{2}$ incubator for $72 \mathrm{~h}$. The culture supernatant was sucked out and MTT $0.5 \mathrm{~g} / \mathrm{L}$ stock solution was added to each well. After $4 \mathrm{~h}$ of incubation, $\mathrm{Me}_{2} \mathrm{SO}$ was added. The optical density of each well was determined by a microplate reader at a wavelength of $570 \mathrm{~nm}$. The values of absorbance were expressed as relative viable cell number.

In vitro transformation of WB-F344 cells WB-F344 cells were seeded on $25-\mathrm{cm}^{2}$ tissue culture flasks containing the complete medium at a density of $4 \times 10^{3}$ cells per flask. The medium was replaced with the complete medium containing $3 \mathrm{MC}(2 \mathrm{mg} / \mathrm{L})$ or $0.1 \% \mathrm{Me}_{2} \mathrm{SO} 24 \mathrm{~h}$ after seeding, and the cells were incubated for another $72 \mathrm{~h}$. After the removal of the medium, the cells were washed twice with sterile phosphate-buffered saline (PBS) and incubated in fresh medium for $4 \mathrm{~d}$. The cells were then incubated with medium containing $100 \mu \mathrm{g} / \mathrm{L} \mathrm{TPA}$. The TPA-containing medium was changed every 2-3 d for $14 \mathrm{~d}$. After sucking out the TPA-containing medium, the cells were washed twice with sterile PBS and then incubated in fresh medium containing $10 \%$ newborn calf serum. The fresh medium was changed every $2 \mathrm{~d}$ until $\mathrm{d} 30$. DDB was added to the medium from $24 \mathrm{~h}$ after cell seeding until the end of the experiment. At d 30, three of these flasks from each group were stained with WrightGiemsa, and scored for transformed colonies. The remainders were used for soft-agar assay.

Soft-agar colony formation assay Cells derived from each group were seeded separately. Agar $(0.6 \%)$ in the complete medium was kept at $44^{\circ} \mathrm{C}$ and poured into 6 -well plates $(2 \mathrm{~mL}$ per well) as to form the lower layer. After the agar medium had set, $1 \times 10^{4}$ cells per well in $2 \mathrm{~mL}$ of $0.3 \%$ agar $\left(44^{\circ} \mathrm{C}\right)$ were layered onto the gelled agar as the form of the upper layer. The cells were incubated in a humidified atmosphere of $95 \%$ air and $5 \% \mathrm{CO}_{2}$ at $37^{\circ} \mathrm{C}$. On d 9 and $\mathrm{d} 18,1 \mathrm{~mL}$ of $0.3 \%$ agar in the complete medium was added. After $28 \mathrm{~d}$, colonies of more than 20 cells were counted under contra-phase microscope.

Cell-cell communication assay The scrape loading/dye transfer (SL/DT) technique was used to detect GJIC according to the method of E1-Fouly et al ${ }^{[12]}$. WB-F344 cells were pretreated with various concentrations of DDB for $1 \mathrm{~h}$ at $24 \mathrm{~h}$ prior to the addition of TPA $(100 \mu \mathrm{g} / \mathrm{L})$ for $1 \mathrm{~h}$. The other cells were pretreated with $4 \mu \mathrm{mol} / \mathrm{L}$ DDB for $24 \mathrm{~h}, 48 \mathrm{~h}$, and $72 \mathrm{~h}$ before treatment with TPA. Following incubation, the cells were washed twice with PBS. Then Lucifer yellow $\mathrm{CH}$ (a fluorescent dye permeating gap-junctional channels) was added and several scrapes were made with a surgical steel-bladed scalpel at low light intensities. These scrapes were performed to ensure that the scrape traversed a large group of confluent cells. After 3 min incubation, the cells were washed with PBS again. Dye migration was observed and photographed with an inverted fluorescent microscope (Olympus, Japan) at $\times 200$ magnification. The number of dyed cells represents the ability of cells to communicate via GJIC. GJIC data are reported as a percentage of the corresponding mean control value. The data are obtained from 3 views per plate, pooled 4 separate plates for each point.

Statistical analysis Results are expressed as mean \pm SD. To compare mean values between 2 groups, the Student's $t$-test was used. $P<0.05$ was considered statistically significant. 


\section{Results}

Cytotoxicity of DDB to WB-F344 cells To select the appropriate doses of DDB for the present study, the cytotoxicity of DDB to WB-F344 cells was assessed using the MTT assay. No significant cytotoxic effect on the cells was observed when the concentrations of DDB were below $4 \mu \mathrm{mol} / \mathrm{L}$ (Table 1). Therefore, $1 \mu \mathrm{mol} / \mathrm{L}, 2 \mu \mathrm{mol} / \mathrm{L}$, and $4 \mu \mathrm{mol} / \mathrm{L}$ of DDB were used in the subsequent experiments.

Table 1. Cytotoxicity of dimethyl dicarboxylate biphenyl (DDB) to WB-F344 rat liver epithelial cells. $n=9$. Mean \pm SD. ${ }^{b} P<0.05$ vs control group.

\begin{tabular}{lcc}
\hline Group & Dose $/ \mu \mathrm{mol} \cdot \mathrm{L}^{-1}$ & Survival rate $\%$ \\
\hline \multirow{2}{*}{ Control } & 0 & $100.0 \pm 0.0$ \\
DDB & 0.5 & $97.9 \pm 13.6$ \\
& 1 & $105.1 \pm 9.3$ \\
2 & $104.9 \pm 12.4$ \\
4 & $90.2 \pm 4.7$ \\
5 & $79.4 \pm 6.9^{\mathrm{b}}$ \\
10 & $78.4 \pm 17.6^{\mathrm{b}}$ \\
& 50 & $79.2 \pm 5.1^{\mathrm{b}}$ \\
& 100 & $61.8 \pm 5.4^{\mathrm{b}}$
\end{tabular}

Effect of DDB on two-stage transformation of WB-F344 cells A two-stage (initiation and promotion) chemical induction oncogenesis model with WB-F344 cells was established. The WB-F344 cells became transformed after 3-MC (2 mg/L) initiation for $72 \mathrm{~h}$ and then TPA $(100 \mu \mathrm{g} / \mathrm{L})$ promotion for $14 \mathrm{~d}$. The transformed cells were grown in a disorganized multilayer instead of in a monolayer (Figure 1). DDB at con- centrations of $1 \mu \mathrm{mol} / \mathrm{L}, 2 \mu \mathrm{mol} / \mathrm{L}$, and $4 \mu \mathrm{mol} / \mathrm{L}$ markedly inhibited transformation of WB-F344 cells in a dosedependent manner. The average number of transformed foci decreased dramatically by $10.0 \%, 37.2 \%$, and $47.4 \%$, respectively, after DDB treatment (Table 2).

Table 2. The inhibitory effect of dimethyl dicarboxylate biphenyl (DDB) on transformed foci in WB-F344 rat liver epithelial cells undergoing initiation with 3-methylcholanthrene (3-MC) followed by promotion with 12 - $O$-tetradecanoyl phorbol 13 -acetate (TPA). $n=3$. Mean \pm SD. ${ }^{\mathrm{b}} P<0.05,{ }^{\mathrm{c}} P<0.01$ vs the model group. Transformed foci/flask: colonies containing $>\sim 100$ cells were scored positive.

\begin{tabular}{lccc}
\hline Group & 3-MC+TPA & $\begin{array}{c}\text { Transformed } \\
\text { foci/plate }\end{array}$ & $\begin{array}{c}\text { Inhibitory } \\
\text { rate/\% }\end{array}$ \\
\hline & & & \\
Control & - & $4.5 \pm 1.3$ & - \\
Model & + & $53.8 \pm 8.2$ & - \\
DDB $1 \mu \mathrm{mol} / \mathrm{L}$ & + & $48.4 \pm 13.4^{\mathrm{b}}$ & 10.0 \\
$2 \mu \mathrm{mol} / \mathrm{L}$ & + & $33.8 \pm 5.1^{\mathrm{c}}$ & 37.2 \\
$4 \mu \mathrm{mol} / \mathrm{L}$ & + & $28.3 \pm 3.3^{\mathrm{c}}$ & 47.4 \\
\hline
\end{tabular}

Effect of DDB on colony of transformed WB-F344 cells in soft agar To evaluate the tumorigenic potential of the treated WB-F344 cells, the efficiency of their soft-agar colony formation was determined. As shown in Table 3, no colony formed in soft agar in untreated WB-F344 cells, whereas the cells initiated with 3-MC and promoted with TPA developed the transformed phenotype of colony formation in soft agar. A remarkable increase in colony numbers was observed. The cells treated with $2 \mu \mathrm{mol} / \mathrm{L}$ and $4 \mu \mathrm{mol} / \mathrm{L}$ DDB also developed the transformed phenotype of colony formation, but the colony numbers significantly decreased compared with
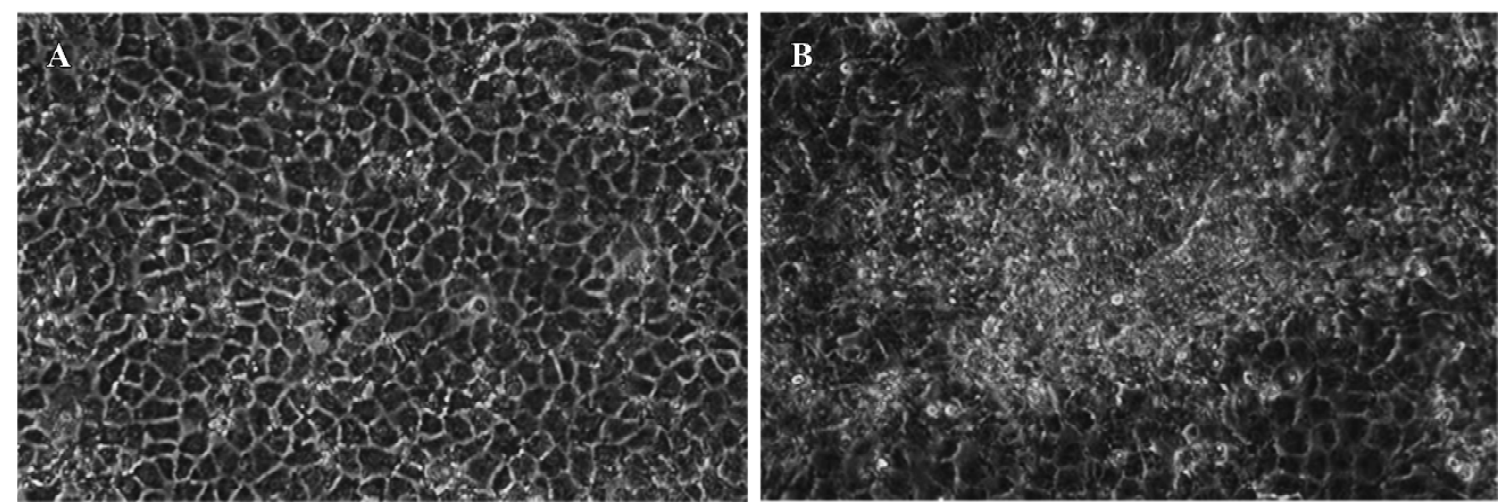

Figure 1. Morphology of WB-F344 cells treated with 3-methylcholanthrene (3-MC)/12-O-tetradecanoyl phorbol 13-acetate (TPA) or the vehicle dimethyl sulfoxide. (A) control cells, (B) cells treated with TPA $100 \mu \mathrm{g} / \mathrm{L}$ plus $3-\mathrm{MC} 2 \mathrm{mg} / \mathrm{L}$. At d 30 of incubation, cell morphology was examined under a microscope $(\times 200)$. Cells treated with $3-\mathrm{MC}$ and TPA were highly transformed in appearance with the formation of foci. 
Table 3. Effect of dimethyl dicarboxylate biphenyl (DDB) on tumorigenicity of transformed WB-F344 rat liver epithelial cells using the soft agar culture assay. $n=3$. Mean \pm SD. ${ }^{c} P<0.01$ vs the model group. Colony forming rate $/ 1 \times 10^{4}$ cells: colonies containing $>\sim 20$ cells were scored positive. 3-MC, 3-methylcholanthrene; TPA, 12$O$-tetradecanoyl phorbol 13 -acetate.

\begin{tabular}{lccc}
\hline Group & 3-MC+TPA & $\begin{array}{c}\text { Colony forming } \\
\text { rate } / 1 \times 10^{4} \text { cells }\end{array}$ & $\begin{array}{c}\text { Inhibitory } \\
\text { rate } / \%\end{array}$ \\
\hline Control & - & $0.0 \pm 0.0$ & - \\
Model & + & $231.0 \pm 17.1$ & - \\
DDB $2 \mu \mathrm{mol} / \mathrm{L}$ & + & $136.0 \pm 19.1^{\mathrm{c}}$ & 41.1 \\
$4 \mu \mathrm{mol} / \mathrm{L}$ & + & $85.0 \pm 7.9^{\mathrm{c}}$ & 63.2 \\
\hline
\end{tabular}

the model group.

Effect of DDB on GJIC The GJIC of normal WB-F344 cells was well- characterized and did not decrease during the experimental incubation period (Figure 2Aa). After exposing the cells to TPA $(100 \mu \mathrm{g} / \mathrm{L})$ for $1 \mathrm{~h}$, over $85 \%$ inhibition of GJIC was detected. The Lucifer yellow $\mathrm{CH}$ only stayed at the incision sites or artificially damaged cells (Figure 2Ab).
When the cells were pretreated with DDB $1 \mu \mathrm{mol} / \mathrm{L}, 2 \mu \mathrm{mol} / \mathrm{L}$, and $4 \mu \mathrm{mol} / \mathrm{L}$, respectively, for $24 \mathrm{~h}$, a dose-dependent inhibition of TPA-induced downregulation of GJC was observed. The GJIC recovered to $25.6 \%, 34.6 \%$, and $44.9 \%$ of the control group, respectively (Figure 2B). The time-dependent inhibitory effect of $4 \mu \mathrm{mol} / \mathrm{L}$ DDB on TPA-induced downregulation of GJIC is shown in Figure 3. By the addition of $4 \mu \mathrm{mol} / \mathrm{L}$ DDB for $24 \mathrm{~h}, 48 \mathrm{~h}$, and $72 \mathrm{~h}$, TPA-induced downregulation of GJIC was markedly reversed in a timedependent manner.

\section{Discussion}

WB-F344 cells have often been used in the study of hepatocarcinogenesis ${ }^{[13]}$. In the present study, we found that the anti-hepatitis drug DDB at non-toxic doses markedly prevented the transformation of WB-F344 cells induced by $3-\mathrm{MC}$ and TPA in vitro, which expressed as significant decrease of the number of transformed foci and the malignant degree of transformed cells.

It is well known that carcinogenesis is a multistage and multimechanism process, involving the irreversible alteration of a stem cell (the initiation phase), followed by the clonal
A
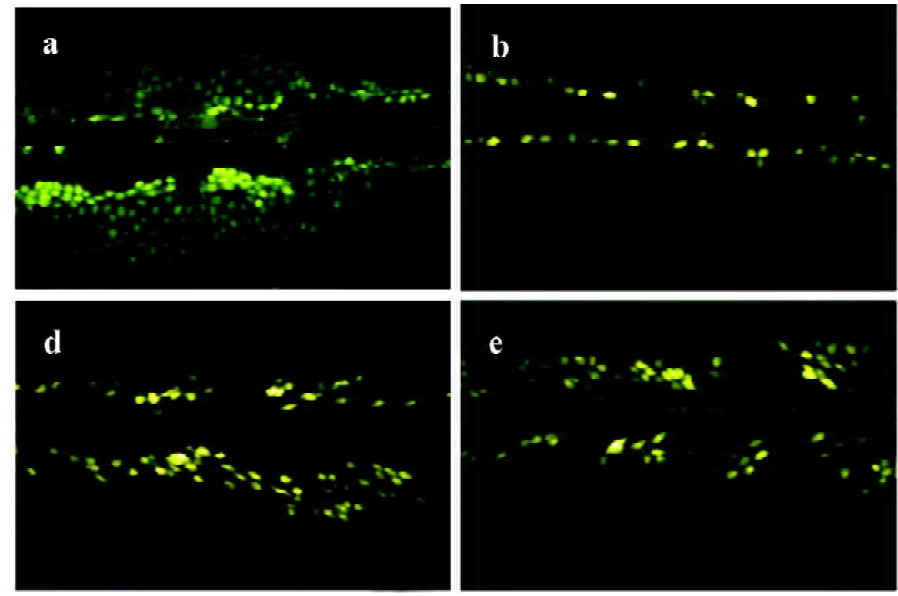

B

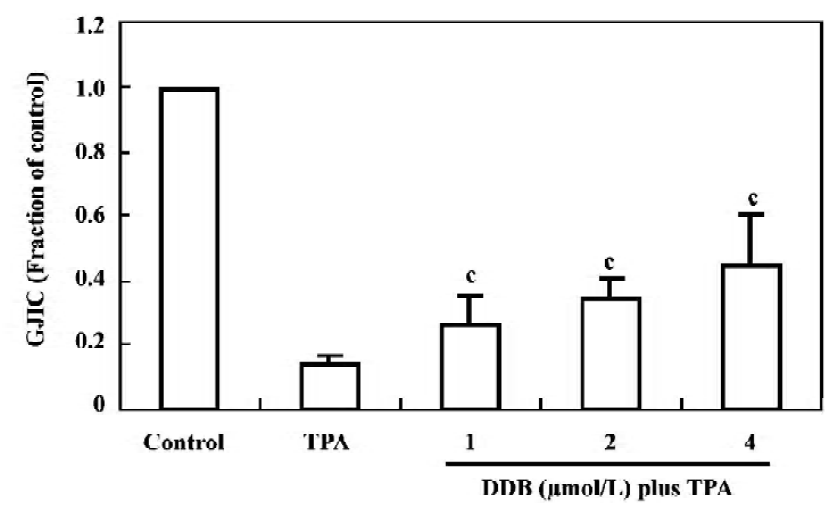

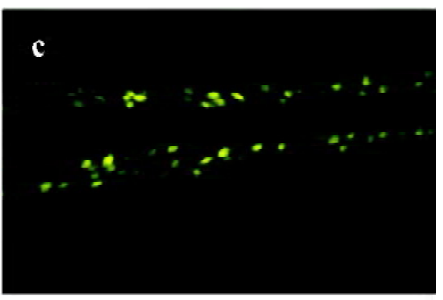

Figure 2. Dose-response of dimethyl dicarboxylate biphenyl (DDB) on 12-O-tetradecanoyl phorbol 13 -acetate (TPA) $100 \mu \mathrm{g} / \mathrm{L}$-induced downregulation of gap junctional intercellular communication(GJIC) in WB-F344 rat liver epithelial cells. (A)(a) control, (b) cells treated with TPA $100 \mu \mathrm{g} / \mathrm{L}$, (c) cells treated with DDB $1 \mu \mathrm{mol} / \mathrm{L}$ plus TPA, (d) cells treated with DDB $2 \mu \mathrm{mol} / \mathrm{L}$ plus TPA, (e) cells treated with DDB $4 \mu \mathrm{mol} / \mathrm{L}$ plus TPA $(\times 200)$. (B) Quantification of recovery rate. Data were expressed as percentage of control. $n=4$. Mean \pm SD. ${ }^{\mathrm{c}} P<0.01 v s$ the TPA model group. 
A
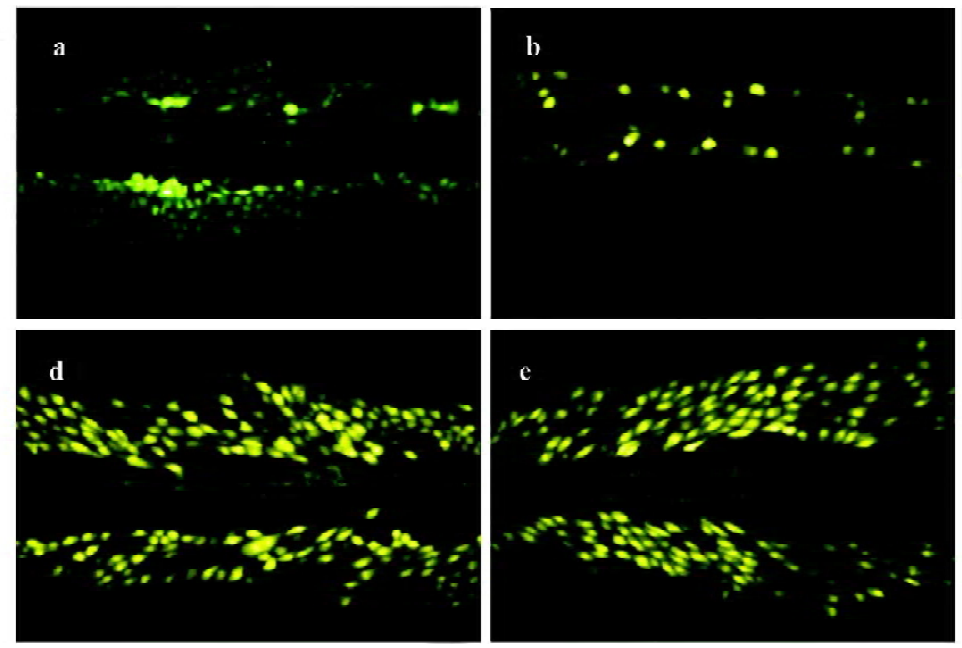

B

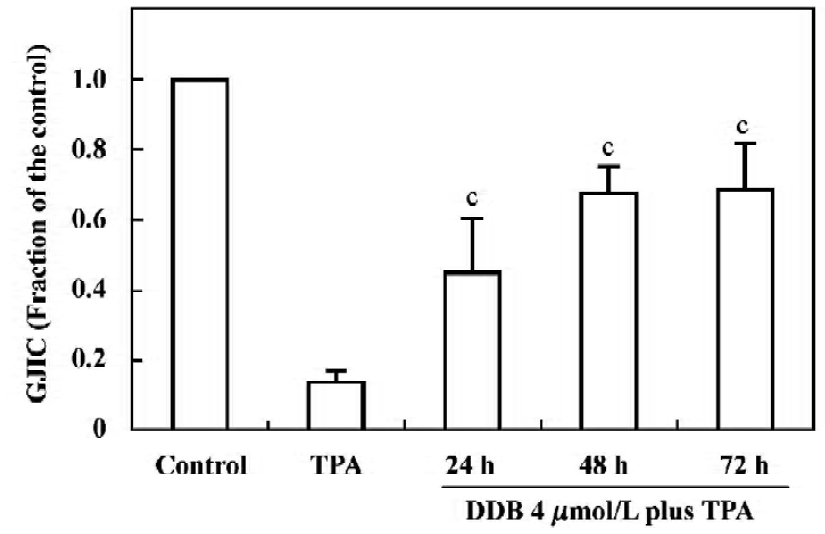

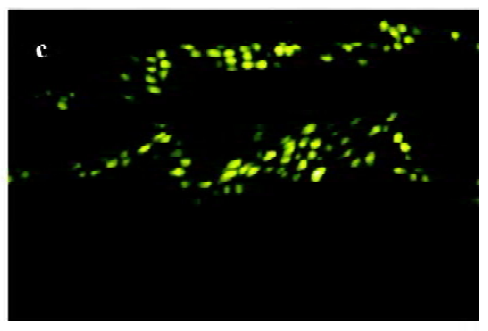

Figure 3. Time course of the inhibitory effect of dimethyl dicarboxylate biphenyl (DDB) on 12-Otetradecanoyl phorbol 13 -acetate (TPA) $100 \mu \mathrm{g} / \mathrm{L}$ induced downregulation of gap junctional intercellular communication(GJIC) in WB-F344 rat liver epithelial cells. (A) (a) control, (b) cells treated with TPA $100 \mu \mathrm{g} / \mathrm{L}$, (c) cells treated with DDB $4 \mu \mathrm{mol} / \mathrm{L}$ for $24 \mathrm{~h}$ plus TPA, (d) cells treated with DDB $4 \mu \mathrm{mol} / \mathrm{L}$ for $48 \mathrm{~h}$ plus TPA, (e) cells treated with DDB $4 \mu \mathrm{mol} / \mathrm{L}$ for $72 \mathrm{~h}$ plus TPA as described in the Materials and Methods ( $\times 200)$. (B) Quantification of recovery rate. Data were expressed as percentage of control. $n=4$. Mean \pm SD. ${ }^{c} P<0.01 v s$ the TPA model group. proliferation of the initiated stem cell (the promotion phase), from which the acquisition of the invasive and metastasis phenotypes are generated (the progression phase). Intervention to prevent cancer can occur at each step. For chemoprevention of carcinogenesis, the development of antitumor promoting agent has been regarded as the most effective pathway.

Intercellular communication is necessary in multicellular organisms to maintain tissue homeostasis and to control cell growth and differentiation. Gap junction channels play an important role in intercellular communication by providing a direct pathway for the movement of molecular information, including ions, polarized and non-polarized molecules up to a molecular mass of $1 \mathrm{kDa}$ between adjacent cells ${ }^{[14,15]}$. Much evidence has been documented to support the hypothesis that the downregulation of GJIC is a cellular event underlying the tumor promotion process, and that any treatment to prevent downregulation of GJIC is important in prevention of tumor promotion ${ }^{[16,17]}$. Many tumor promoters have been shown to inhibit gap junctional communication in vitro ${ }^{[18,19]}$. TPA is a well-known classical inhibitor of cell communication in most cells, including the WB-F344 cell ${ }^{[20]}$. In the present study, the underlying mechanisms of DDB against hepatocarcinogenesis were investigated during the promotional phase using TPA to inhibit GJIC. The WB-F344 cells are known to have high GJIC. The treatment with TPA significantly inhibited GJIC, as was determined using the SL/DT assay. The counteracting effect of DDB on GJIC inhibition caused by TPA suggests that DDB has a significant action in maintaining GJC function, and that it might be beneficial in preventing tumor promotion.

In summary, the results of the present study suggest that DDB can prevent the malignant transforming of WBF344 cells induced by 3-MC and TPA in vitro. The restoration of GJIC in the promotion phase should contribute, at least in part, to the anti-hepatocarcinogenic property of DDB. We conducted other experiments and found that DDB significantly inhibited liver carcinogenesis induced by DEN/PB in mice; the data from these experiments will be published in another paper soon. Both in vitro and in vivo experiments 
demonstrated that DDB had a chemopreventive effect on hepatocarcinogenesis. It is worthy to pay attention to whether DDB potentially prevents liver carcinogenesis in patients with chronic viral hepatitis.

\section{References}

1 Feitelson MA, Pan J, Lian Z. Early molecular and gentic determinants of primary liver malignancy. Surg Clin N Am 2004; 84: 339-54.

2 Yerian LM, Anders RA, Tretiakova M, Hart J. Caveolin and thrombospondin expression during hepatocellular carcinogenesis. Am J Surg Pathol 2004; 28: 357-63.

3 Birrer RB, Birrer D, Klavins JV. Review: Hepatocellular carcinoma and hepatitis virus. Ann Clin Lab Sci 2003; 33: 39-54.

4 Robert S, Brown J, Paul JG. Scope of worldwide hepatitis C problem. Liver Transpl 2003; 9: s10-s13.

5 Glinghammar B, Skogsberg J, Hamsten A, Ehrenborg E. PPARä activation induces COX-2 gene expression and cell proliferation in human hepatocellular carcinoma cells. Biochem Biophys Res Commun 2003; 308: 361-8.

6 Liu GT. From the study of Fructus Schizandrae to the discovery of biphenyl dimethyl-dicarboxylate. Acta Pharm Sin 1983; 18: 714-20.

7 Liu GT, Wang GF, Wei HL, Bao TT, Song ZY. A comparison of the protective actions of biphenyl dimethyl-dicarboxylate, transstilbene, alcoholic extracts of Fructus Schizandrae and ganoderma against expeimental liver injury in mice. Acta Pharm Sin 1979; 14: 598-604.

8 Liu GT, Wei HL, Song ZY. Further studies on the protective action of biphenyl dimethyl-dicarboxylate (BDD) against experimental liver injury in mice. Acta Pharm Sin 1982; 17: $101-6$.

9 Wang GX, Ben CE, Ye BK, Yang M, Gao JL. Reparative effects of biphenyl dimethyl dicarboxylate on experimental liver injury in rats with histochemical and electronmicroscopy study. Chin J Integrat Tradit Western Med 1988; 8: 158-60.

10 Liu ZY, Cui Q, Fu T, Liu GT. Inducing effect of dimethy-4,4'dimethoxy-5,6,5',6-dimethylenedioxybipheny-2,2'-dicarboxylate
(DDB) on differentiation of leukemia HL-60 cells. Natl Med J China 1996; 76: 214-7.

11 Mosmann T. Rapid colorimetric assay for cellular growth and survival: application to proliferation and cytotoxicity assays. J Immunol Methods 1983; 65: 55-63.

12 El-Fouly MH, Trosko JE, Chang CC. Scrape-loading and dye transfer: A rapid and simple technique to study gap junctional intercellular communication. Exp Cell Res 1987; 168: 422-30.

13 Tsao MS, Smith JD, Nelson KG, Grisham JW. A diploid epithelial cell line from normal adult rat liver with phenotypic properties of "oval" cells. Exp Cell Res 1984; 154: 38-52.

14 Cho JH, Cho SD, Hu H, Kim SH, Lee SK, Lee YS, et al. The role of ERK1/2 and p38 MAP kinase in the preventive mechanisms of mushroom phellinus linteus against the inhibition of gap junctional communication by hydrogen peroxide. Carcinogenesis 2002; 23: 1163-9.

15 Simon AM, Goodenough DA. Diverse functions of vertrbrate gap junction. Trends Cell Biol 1998; 8: 477-83.

16 Niloofar A-A, Wilhelm S, Helmut S. (-)-Epicatechin effects in rat liver epithelial cells: stimulation of gap junctional communication and counteraction of its loss due to the tumor promoter 12-O-tetradecanoylthorbol-13-acetate. Biochem Pharm 2002; 63: 2145-9.

$17 \mathrm{Hu}$ J, Engman L, Cotgreave IA. Redox-actine chalcogen-containing glutathione peroxidase minetics and antioxidants inhibit tumour promoter-induced downregulation of gap junctional intercellular communication between WB-F344 liver epithelial cells. Carcinogenesis 1995; 16: 1815-24.

18 Guan X, Randall GR. Gap junction endocytosis and lysosomal degradation of connexin43-P2 in WB-F344 rat liver epithelial cells treated with DDT and lindane. Carcinogenesis 1996; 17: 1791-8.

19 Ping R, Parmender PM, Randall JR. Inhibition of gap junctional intercellular communication by tumor promoters in connexin 43 and connexin32-expressing liver cells: Cell specificity and role of protein kinase C. Carcinogenesis 1998; 19: 169-75.

20 Kang KS, Kang BC, Lee BJ, Che JH, Li GX, Trosko JE, et al. Preventive effent of epicatechin and ginsenoside $\mathrm{Rb} 2$ on the inhibition of gap junctionsl intercellular communication by TPA and $\mathrm{H}_{2} \mathrm{O}_{2}$. Cancer Lett 2000; 152: 97-106. 